\title{
Effect of intra-row spacing on growth and yield of two eggplant (Solanum melongena L.) cultivars under Blue Nile State conditions, Sudan
}

\author{
Faiha I. M. Hassan, Eisa Y. A. and Adlan M. A. Adlan* \\ Damazine Research Station, Sudan.
}

Accepted 16 March, 2018

\begin{abstract}
Experiments were carried out in Damazin Research Station during summer 2016 and 2017 to determine the effect of intra-row spacing on two eggplant (Solanum melongena L.) cultivars growth and yield. The treatments used are three intra-row spacing viz. 30, 40 and $50 \mathrm{~cm}$ with two cultivars (Wizo and black beauty), the experiments were arranged in a Randomized Complete Block Design with three replications. The data collected including growth and yield parameters was analyzed using the GenStat statistical package. Results show that that Wizo cultivar recorded the best statements than black beauty cultivar. The wide spacing $(50 \mathrm{~cm}$ and 40$)$ intra-row spacing recorded the highest number of leaves/plant, number of fruits/plant and fruit length $(\mathrm{cm})$. The 30 and $40 \mathrm{~cm}$ intra-row spacing and Wizo gave the greatest yield (tons/ha) in two seasons. The study advised to use Wizo cultivar and $40 \mathrm{~cm}$ intra row-spacing is appropriate to cultivate eggplant in Blue Nile State Sudan.
\end{abstract}

Keywords: Wizo, black beauty, intra-row spacing, Blue Nile State, Sudan.

*Corresponding author. E-mail: adlan.m.a.2015@gmail.com.

\section{INTRODUCTION}

Eggplant (Solanum melongena L.) is a short-lived perennial herb that belongs to the family Solanaceae. It is grown as an annual plant and is one of the most consumed fruit vegetables in tropical Africa; probably the third after tomato and onion, and before okra (Grubben and Denton, 2004). It is an economically important crop in Asia, Africa and the sub-tropics (India, Central America) and it is also cultivated in some warm temperate regions of the Mediterranean and South America (Sihachkr et al., 1993). It is a good source of minerals and vitamins (particularly iron) making its total nutritional value comparable with tomato (Kalloo, 1993). Today, eggplant is cultivated worldwide and has a growing reputation (Doganlar et al., 2002). It is one of the most important vegetable crops grown in many parts of the Sudan all the year round. It is produced mainly for local consumption and small quantities for export.

Yield increases due to increased plant stand eventually reach a point at which increasing the seed rate did not increase the overall yield (Tivoli et al., 1996). Manipulation of plant populations, through varied seed rates and seed placement is a critical management tool that can be used to modify crop productivity (Johnston et al., 2002). Although eggplant is cultivated almost in all parts of Sudan, little work has been done on knowing the methods of cultivation and crop raising patterns to get the high plant production. Farmers grow eggplant by deference method and plant density such as ridges 70 and $120 \mathrm{~cm}$ and intra-row spacing between 40 and 50 $\mathrm{cm}$. The objective of the current work was to study the effect of intra-row spacing on performance of tow cultivars of eggplant in the Blue Nile State, Sudan.

\section{MATERIALS AND METHODS}

Experiments were carried out at the farm of the Damazin Research Station in Blue Nile State, Sudan during summer seasons of 2016 
and 2017, to evaluate the effect of intra-row spacing on two eggplant cultivars growth and yield components. Two cultivars (Wizo and black beauty) with three intra-row spacing (30, 40 and 50 $\mathrm{cm}$ ) were used on the experiment, six treatments were arranged in split block design (SBD) with three replications. The experimental unit was four ridges $70 \mathrm{~cm}$, with a plot size of $3 \mathrm{~m}$ long $\times 0.7 \mathrm{~m}$, and $2.5 \mathrm{~m}$ long $\times 0.7 \mathrm{~m}$, in the two seasons respectively. The transplanting was done in the evening after 6 weeks in two seasons (second week of February) in the summer seasons. $2 \mathrm{~N}$ fertilizer (as urea) was applied to the seedlings after establishment at 4 and 8 weeks after transplanting, irrigation, hand weeding and pest control were used when necessary. Data were collected from five plants randomly selected from each plot for growth parameters, while yield characteristics were measured during the harvesting period of the crop. Growth parameters include plant height $(\mathrm{cm})$, number of leaves/plant, and number of vegetative branches/plant. Yield parameters were include number of fruits branches/plant and yield parameters such as number of fruits/plant, single fruit weight $(\mathrm{g})$ and total yield (tons/ha). The data were subjected to ANOVA using the GenStat software package (Buysse et al., 2004).

\section{RESULTS}

Table 1 results show that intra-row spacing did not have significant effects on days to $50 \%$ flowering in two seasons, while cultivar had significant effects. Generally black beauty cultivar manifested early flowering than Wizo cultivar in two seasons.

Table 2 results show that there is significant interaction between intra-row spacing and cultivars in terms plant height and number of leaves/plant in two seasons, except for interaction was not effects in season 2017. The greatest plant height and number of leaves/plant were obtained by $50 \mathrm{~cm}$ intra-row spacing in two seasons with no significant difference than $40 \mathrm{~cm}$ intra-row spacing in season 2016; while intra-row spacing $(40 \mathrm{~cm})$ recorded the greatest plant height in season 2016. The cultivar Wizo was gave the greatest plant height and number of leaves/plant. The interaction of Wizo with $50 \mathrm{~cm}$ intra-row spacing gave the greatest plant height and number of leaves/plant

Table 3 results show that the number of vegetative and fruit branches/plant were significantly affected by intrarow spacing, cultivars, and their interaction in two seasons, except the effect of interaction on number of vegetative branches/plant on season 2017 . Generally the 40 and $50 \mathrm{~cm}$ intra-row spacing and cultivar Black beauty gave the greatest number of vegetative and fruit branches/plant in two season.

Table 4 shows that intra-row spacing and cultivars significantly affected the number of fruits/plant and single fruit weight $(\mathrm{g})$ in two seasons; while the interaction was effect on single fruit weight $(\mathrm{g})$ in season 2017 . The intrarow spacing of 40 and $50 \mathrm{~cm}$ and Wizo cultivar gave the greatest number of fruits/plant and single fruit weight $(\mathrm{g})$ in two seasons.

Table 5 showed that intra-row spacing and cultivars had significant effects on fruit length $(\mathrm{cm})$ and fruit girth $(\mathrm{cm})$ in two seasons; while the interaction has significant effect in season one only. The $50 \mathrm{~cm}$ intra-row spacing had greatest highest length and fruit girth in both seasons. The Wizo cultivar gave the greatest fruit length and black beauty cultivar gave the greatest fruit girth. The interaction of $50 \mathrm{~cm}$ intra-row spacing with Wizo cultivar gave the greatest fruit length and with black beauty cultivar gave the greatest fruit girth.

Table 1. Effects of intra-row spacing, cultivars and their interaction on days to $50 \%$ flowering of eggplant over two seasons at Damazin Research Station.

\begin{tabular}{|c|c|c|c|c|c|c|}
\hline \multirow{3}{*}{ Intra-row spacing $(\mathrm{cm})$} & \multicolumn{6}{|c|}{ Days to $50 \%$ flowering } \\
\hline & \multicolumn{3}{|c|}{ Summer 2016} & \multicolumn{3}{|c|}{ Summer 2017} \\
\hline & Wizo & BI. B. & Mean & Wizo & BI. B. & Mean \\
\hline 30 & 58 & 55 & 56 & 56 & 54 & 55 \\
\hline 40 & 59 & 55 & 56 & 57 & 54 & 56 \\
\hline 50 & 58 & 54 & 56 & 57 & 54 & 55 \\
\hline Mean & $59 \mathrm{~A}$ & $54 \mathrm{~B}$ & & $57 \mathrm{~A}$ & $54 \mathrm{~B}$ & \\
\hline Statistics & Sig. & SE \pm & CV\% & Sig. & SE \pm & CV\% \\
\hline Spacing & NS & - & & NS & - & \\
\hline Cultivars & $* *$ & 1.05 & 3.9 & *** & 0.37 & 2.0 \\
\hline Interaction & NS & - & & NS & - & \\
\hline
\end{tabular}

Table 6 showed that intra-row spacing had significant effect on yield tons/ha in both seasons; while cultivars had effect in season two only. The interaction had no significant effect in both seasons. Generally, the 30 and $40 \mathrm{~cm}$ intra-row spacing and Wizo gave the greatest yield (tons/ha) in both seasons. 
Table 2. Effects of intra-row spacing, cultivars and their interaction on plant height (cm) and number of leaves/plant of eggplant over two seasons at Damazin Research Station.

\begin{tabular}{|c|c|c|c|c|c|c|c|c|c|c|c|c|}
\hline \multirow{3}{*}{$\begin{array}{l}\text { Intra-row } \\
\text { spacing (cm) }\end{array}$} & \multicolumn{6}{|c|}{ Plant height (cm) } & \multicolumn{6}{|c|}{ Number of leaves /plant } \\
\hline & \multicolumn{3}{|c|}{ Summer 2016} & \multicolumn{3}{|c|}{ Summer 2017} & \multicolumn{3}{|c|}{ Summer 2016} & \multicolumn{3}{|c|}{ Summer 2017} \\
\hline & Wizo & BI. B. & Mean & Wizo & BI. B. & Mean & Wizo & BI. B. & Mean & Wizo & BI. B. & Mean \\
\hline 30 & $53.4^{b}$ & $41.7^{d}$ & $47.6^{\mathrm{B}}$ & $70.5^{b}$ & $45.3^{c}$ & $57.9^{C}$ & 48 & 50 & $49^{B}$ & 51 & 48 & $49^{C}$ \\
\hline 40 & $63.8^{\mathrm{a}}$ & $47.0^{c}$ & $55.4^{\mathrm{A}}$ & $75.1^{\mathrm{a}}$ & $48.3^{d}$ & $61.7^{\mathrm{B}}$ & 53 & 51 & $52^{A B}$ & 55 & 52 & $54^{\mathrm{B}}$ \\
\hline 50 & $68.3^{\mathrm{a}}$ & $38.4^{\mathrm{e}}$ & $53.4^{\mathrm{A}}$ & $77.4^{\mathrm{a}}$ & $54.4^{\mathrm{c}}$ & $65.9^{\mathrm{A}}$ & 55 & 51 & $53^{A}$ & 59 & 55 & $57^{\mathrm{A}}$ \\
\hline Mean & $61.8^{A}$ & $42.4^{\mathrm{B}}$ & & $74.4^{\mathrm{A}}$ & $49.3^{B}$ & & $52^{\mathrm{A}}$ & $51^{\mathrm{B}}$ & & $55^{\mathrm{A}}$ & $52^{B}$ & \\
\hline \multicolumn{13}{|l|}{ Statistics } \\
\hline Spacing & $\underset{* \star \star}{\text { Sig. }}$ & $\begin{array}{c}\text { SE } \pm \\
1.3\end{array}$ & CV\% & $\underset{* \star \star}{\text { Sig. }}$ & $\begin{array}{c}\text { SE } \pm \\
0.6\end{array}$ & CV\% & $\underset{* \star}{\text { Sig. }}$ & $\begin{array}{c}\mathrm{SE} \pm \\
1.1\end{array}$ & CV\% & $\underset{* \star \star}{\text { Sig. }}$ & $\begin{array}{l}\text { SE } \pm \\
0.39\end{array}$ & CV\% \\
\hline Cultivars & $* * *$ & 1.1 & 4.6 & * & 0.5 & 2.1 & $* * *$ & 0.9 & 4.3 & $* * *$ & 0.32 & 1.8 \\
\hline Interaction & $\star * *$ & 1.9 & & * & 0.8 & & NS & - & & NS & - & \\
\hline
\end{tabular}

${ }^{*},{ }^{* *},{ }^{* * *}$ and NS indicate $=$ Significant at $\mathrm{p} \geq 0.05, \mathrm{P}=0.001, \mathrm{P} \leq 0.001$ and not significantly respectively. BI. B. = Black beauty cultivar.

Table 3. Effects of intra-row spacing, cultivars and their interaction on number of vegetative and fruit branches/plant of eggplant over two seasons at Damazin Research Station.

\begin{tabular}{|c|c|c|c|c|c|c|c|c|c|c|c|c|}
\hline \multirow{3}{*}{$\begin{array}{l}\text { Intra-row } \\
\text { spacing (cm) }\end{array}$} & \multicolumn{6}{|c|}{ Number of vegetative branches/plant } & \multicolumn{6}{|c|}{ Number of fruit branches/plant } \\
\hline & \multicolumn{3}{|c|}{ Summer 2016} & \multicolumn{3}{|c|}{ Summer 2017} & \multicolumn{3}{|c|}{ Summer 2016} & \multicolumn{3}{|c|}{ Summer 2017} \\
\hline & Wizo & BI. B. & Mean & Wizo & BI. B. & Mean & Wizo & BI. B. & Mean & Wizo & BI. B. & Mean \\
\hline 30 & 5.6 & 5.9 & $5.8^{\mathrm{B}}$ & 11.2 & 13.6 & $12.4^{\mathrm{C}}$ & $5.4^{\mathrm{C}}$ & $5.7^{\mathrm{ab}}$ & $5.6^{\mathrm{C}}$ & 3.9 & 4.0 & $3.9^{\mathrm{C}}$ \\
\hline 40 & 5.9 & 6.2 & $6.0^{\mathrm{A}}$ & 16.9 & 16.3 & $16.6^{\mathrm{B}}$ & $5.7^{\mathrm{ab}}$ & $5.8^{\mathrm{a}}$ & $5.8^{\mathrm{A}}$ & 6.0 & 5.2 & $5.6^{\mathrm{B}}$ \\
\hline 50 & 5.9 & 6.1 & $6.0^{A}$ & 16.9 & 18.2 & $17.5^{\mathrm{A}}$ & $5.6^{b}$ & $5.8^{\mathrm{a}}$ & $5.7^{\mathrm{B}}$ & 8.1 & 6.1 & $7.1^{\mathrm{A}}$ \\
\hline Mean & $5.8^{\mathrm{B}}$ & $6.0^{A}$ & & $15.0^{B}$ & $16.1^{A}$ & & $5.6^{\mathrm{B}}$ & $5.8^{\mathrm{A}}$ & & $6.0^{\mathrm{A}}$ & $5.1^{B}$ & \\
\hline \multicolumn{13}{|l|}{ Statistics } \\
\hline & Sig. & $\mathrm{SE} \pm$ & CV\% & Sig. & $\mathrm{SE} \pm$ & CV\% & Sig. & $\mathrm{SE} \pm$ & CV\% & Sig. & $\mathrm{SE} \pm$ & CV\% \\
\hline Spacing & * & 0.08 & & * & 0.04 & & $* * *$ & 0.17 & & $* * *$ & 0.27 & \\
\hline Cultivars & * & 0.06 & 2.3 & $* * *$ & 0.03 & 1.3 & * & 0.04 & 2.7 & * & 0.22 & 12.0 \\
\hline Interaction & NS & - & & NS & 0.05 & & $* * *$ & 0.04 & & NS & - & \\
\hline
\end{tabular}

${ }^{*},{ }^{* *}$ and NS indicate $=$ Significant at $\mathrm{p} \geq 0.05, \mathrm{P} \leq 0.001$ and not significantly respectively. BI. B. = Black beauty cultivar. 


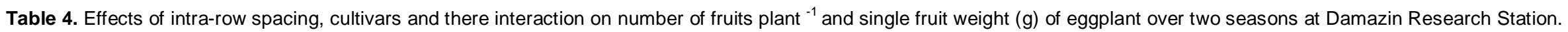

\begin{tabular}{|c|c|c|c|c|c|c|c|c|c|c|c|c|}
\hline \multirow{3}{*}{$\begin{array}{l}\text { Intra-row } \\
\text { spacing (cm) }\end{array}$} & \multicolumn{6}{|c|}{ Number of fruits /plant } & \multicolumn{6}{|c|}{ Single fruit weight (g) } \\
\hline & \multicolumn{3}{|c|}{ Summer 2016} & \multicolumn{3}{|c|}{ Summer 2017} & \multicolumn{3}{|c|}{ Summer 2016} & \multicolumn{3}{|c|}{ Summer 2017} \\
\hline & Wizo & BI. B. & Mean & Wizo & BI. B. & Mean & Wizo & BI. B. & Mean & Wizo & BI. B. & Mean \\
\hline 30 & 9 & 9 & $9 B$ & 4 & 3 & $3.5 \mathrm{C}$ & 126.7 & 142.0 & 134.3 & $133.7^{c}$ & $122.7^{d}$ & $128.2^{C}$ \\
\hline 40 & 11 & 10 & $11^{A}$ & 6 & 4 & $5 B$ & 131.0 & 145.3 & 138.2 & $137.0^{b}$ & $132.0^{c}$ & $134.5^{\mathrm{B}}$ \\
\hline 50 & 11 & 11 & $11^{\mathrm{A}}$ & 7 & 5 & $6 \mathrm{~A}$ & 135.7 & 149.0 & 142.3 & $148.3^{a}$ & $135.3^{\mathrm{bc}}$ & $141.8^{\mathrm{A}}$ \\
\hline Mean & $11^{\mathrm{A}}$ & $10^{\mathrm{B}}$ & & $5.7^{\mathrm{A}}$ & $4.0^{\mathrm{B}}$ & & $131.1^{\mathrm{B}}$ & $145.4^{\mathrm{A}}$ & & $139.7^{\mathrm{A}}$ & $130.0^{\mathrm{B}}$ & \\
\hline \multicolumn{13}{|l|}{ Statistics } \\
\hline Spacing & $\underset{*}{\text { Sig. }}$ & $\begin{array}{l}\text { SE } \pm \\
0.05\end{array}$ & CV\% & $\underset{\star}{\text { Sig. }}$ & $\begin{array}{l}\text { SE } \pm \\
0.06\end{array}$ & CV\% & $\underset{* \star \star}{\text { Sig. }}$ & $\begin{array}{l}\text { SE } \pm \\
0.43\end{array}$ & CV\% & $\underset{* \star \star}{\text { Sig. }}$ & $\begin{array}{l}\text { SE } \pm \\
0.85\end{array}$ & CV\% \\
\hline Cultivars & * & 0.04 & 9 & $* * *$ & 0.1 & 1.3 & $* *$ & 0.35 & 15.8 & $* * *$ & 0.70 & 1.5 \\
\hline Interaction & NS & - & & NS & - & & NS & - & & $* *$ & 1.21 & \\
\hline
\end{tabular}

${ }^{*},{ }^{* *}{ }^{* *}$ and NS indicate $=$ Significant at $\mathrm{p} \geq 0.05, \mathrm{P}=0.001, \mathrm{P} \leq 0.001$ and not significantly respectively. BI. B. = Black beauty cultivar.

Table 5. Effects of intra-row spacing, cultivars and there interaction on fruit length (cm) and fruit girth (cm) of eggplant over two seasons at Damazin Research Station.

\begin{tabular}{|c|c|c|c|c|c|c|c|c|c|c|c|c|}
\hline \multirow{3}{*}{$\begin{array}{l}\text { Intra-row } \\
\text { spacing (cm) }\end{array}$} & \multicolumn{6}{|c|}{ Fruit length (cm) } & \multicolumn{6}{|c|}{ Fruit girth (cm) } \\
\hline & \multicolumn{3}{|c|}{ Summer 2016} & \multicolumn{3}{|c|}{ Summer 2017} & \multicolumn{3}{|c|}{ Summer 2016} & \multicolumn{3}{|c|}{ Summer 2017} \\
\hline & Wizo & BI. B. & Mean & Wizo & BI. B. & Mean & Wizo & BI. B. & Mean & Wizo & BI. B. & Mean \\
\hline 30 & 14.7 & 12.0 & 13.3 & 15.0 & 12.4 & 13.861 & $21.3^{\mathrm{e}}$ & $22.9^{d}$ & $22.1^{\mathrm{B}}$ & $22.5^{d}$ & $23.3^{d}$ & $22.9^{C}$ \\
\hline 40 & 17.2 & 13.0 & 15.1 & 17.7 & 14.0 & 16.014 & $24.3^{c}$ & $25.3^{\mathrm{b}}$ & $24.8^{\mathrm{AB}}$ & $24.1^{d}$ & $26.7^{\mathrm{b}}$ & $25.4^{\mathrm{B}}$ \\
\hline 50 & 18.8 & 14.7 & 16.75 & 17.0 & 15.7 & 16.333 & $25.3^{b}$ & $27.3^{\mathrm{a}}$ & $26.3^{A}$ & $25.5^{c}$ & $28.3^{\mathrm{a}}$ & $26.9^{A}$ \\
\hline Mean & $16.9^{A}$ & $13.2^{\mathrm{B}}$ & & $16.7^{\mathrm{A}}$ & $14.13^{\mathrm{B}}$ & & $23.6^{\mathrm{B}}$ & $25.2^{A}$ & & $24.3^{\mathrm{B}}$ & $26.1^{\mathrm{A}}$ & \\
\hline \multicolumn{13}{|l|}{ Statistics } \\
\hline & Sig. & $\mathrm{SE} \pm$ & CV\% & Sig. & $\mathrm{SE} \pm$ & CV\% & Sig. & $\mathrm{SE} \pm$ & $\mathrm{CV} \%$ & Sig. & $\mathrm{SE} \pm$ & CV\% \\
\hline Spacing & $* * *$ & 0.36 & & $* * *$ & 0.36 & & $* * *$ & 0.13 & & $* * *$ & 0.27 & \\
\hline Cultivars & $* * *$ & 0.30 & 5.9 & ** & 0.30 & 3.7 & $* * *$ & 0.11 & 2.1 & $* * \star$ & 0.22 & 2.6 \\
\hline Interaction & NS & - & & NS & - & & $* * *$ & 0.18 & & * & 0.38 & \\
\hline
\end{tabular}

${ }^{*},{ }^{* * *}$ and NS indicate $=$ Significant at $\mathrm{p} \geq 0.05, \mathrm{P} \leq 0.001$ and not significantly respectively. BI. B. = Black beauty cultivar. 
Table 6. Effects of intra-row spacing, cultivars and there interaction on marketable yield of eggplant over two seasons at Damazin Research Station.

\begin{tabular}{|c|c|c|c|c|c|c|}
\hline \multirow{3}{*}{ Intra-row spacing (cm) } & \multicolumn{6}{|c|}{ Marketable yield (tons /ha) } \\
\hline & \multicolumn{3}{|c|}{ Summer 2016} & \multicolumn{3}{|c|}{ Summer 2017} \\
\hline & Wizo & BI. B. & Mean & Wizo & BI. B. & Mean \\
\hline 30 & 12.3 & 12.8 & $12.6^{\mathrm{A}}$ & 32.2 & 25.1 & $28.7^{\mathrm{A}}$ \\
\hline 40 & 11.3 & 11.0 & $11.1^{\mathrm{AB}}$ & 28.4 & 24.0 & $26.2^{\mathrm{A}}$ \\
\hline 50 & 9.9 & 10.2 & $10.1^{B}$ & 23.1 & 17.0 & $20.0^{\mathrm{B}}$ \\
\hline Mean & 11.2 & 11.3 & & $27.9^{\mathrm{A}}$ & $22.1^{\mathrm{B}}$ & \\
\hline \multicolumn{7}{|l|}{ Statistics } \\
\hline & Sig. & SE \pm & CV\% & Sig. & $\mathrm{SE} \pm$ & CV\% \\
\hline Spacing & * & 0.5 & & $* \star *$ & 1.1 & \\
\hline Cultivars & NS & - & 8.6 & $* * *$ & 0.90 & 10.8 \\
\hline Interaction & NS & - & & NS & - & \\
\hline
\end{tabular}

${ }^{*},{ }^{* * *}$ and NS indicate $=$ Significant at $\mathrm{p} \geq 0.05, \mathrm{P} \leq 0.001$ and not significantly respectively. Bl. B. = Black beauty cultivar.

\section{DISCUSSION}

The $30 \mathrm{~cm}$ intra-row spacing recorded the lowest plant height. This result disagrees with Afzal et al. (2004) who studied the effects of various row spacing $(60,70$ and 80 $\mathrm{cm}$ ) on the growth characteristics of different chilli pepper. They reported that highest plant was recorded at closer row spacing $(60 \mathrm{~cm})$, while the shortest plant height was recorded at $80 \mathrm{~cm}$ row spacing. The results of the present study indicated that $30 \mathrm{~cm}$ intra row spacing (closer planting) recorded lowest number of fruits/plant, that is agreed with Hanna et al. (1987), who found that the number of fruit per plant increased with spacing in eggplant and cucumber (Cucumis sativus), respectively. On the other hand, $50 \mathrm{~cm}$ intra row spacing recorded lowest yield tons/ha in two seasons. This result disagrees with Benedictos (2000) who examined the effect of sowing patterns based on plant and row spacing for brinjal, and ridge sowing at $100 \times 40 \mathrm{~cm}$ spacing intra and inter row spacing showed the highest mean yields of 40 tons $^{-1}{ }^{-1}$ Kogbe, 1983).

\section{Conclusion}

Significant effects of intra-row spacing and cultivars on all parameters were tested in this study. The $40 \mathrm{~cm}$ intra-row spacing gave same yield with $30 \mathrm{~cm}$ intra-row spacing and highest number of fruits/plant, fruit length $(\mathrm{cm})$ and fruit girth $(\mathrm{cm})$ with same to $50 \mathrm{~cm}$ intra-row spacing. The cultivar wizo gave the greatest plant height, number of leaves/plant, number of fruits/plant and single fruit weight (g), fruit length and yield (tons/ha). This present results demonstrated that:

- $\quad$ The wizo cultivar was appropriate to cultivate in Blue Nile State, Sudan.
- $\quad$ The $40 \mathrm{~cm}$ intra-row spacing was appropriate to planting eggplant in Blue Nile State, Sudan.

\section{REFERENCES}

Afzal S, Muhammad S, Khan H. 2004. Growth characteristics of chilli cultivar as affected by various row spacings. Sarhad J Agric, 20(2): 4450.

Benedictos PJR, 2000. Optimum planting density for eggplant cV. 'Avan'. Acta Horticulturae, 533: 167-169.

Buysse W, Stern R, Coe R, 2004. Gen Stat Discovery Edition for Everyday Use. ICRAF Nirobi, Kenya. 114 pp.

Doganlar S, Frary A, Daunay C, Lester N, Tanskley S, 2002. A comparative genetic linkage map of eggplant (Solanum melongena) and its implication for genome evolution in the Solanaceae. Genetics, 161: 1697-1711.

Grubben GJH, Delton DA, 2004. Plant Resources of Tropical Africa Vegetables. PROTA Foundation, Wageringen, Netherlands, Blackhuys Publishers, Leiden. CTA, Wagenringen, Netherlands 668 pp.

Hanna HY, Adams AJ, Story RN, 1987. Increased yield in slicing cucumber with vertical training of plants and reduced plant spacing. Hort Sci, 22: 32-34.

Kalloo G, 1993. Eggplant, solanum melongena L. In Kalloo, G., Berge, B. O(ed). Genetic improvement of vegetable crops 587-604. Pergamon Press, Oxford, UK. Protoplasts and Genetic Engineering. Springer, Berlin, pp. 108-122.

Kogbe JOS, 1983. Effects of spacing on the yield of local and exotic species of Nigeria. 6(2): 45-50.

Sihachkr D, Chaput MH, Serraf L, Ducreux G, 1993. Regeneration of plants from protoplasts of eggplant (Solanum melongena L.). In: Bajaj, Y.P.S. (Ed.), Biotechnology in Agriculture and Forestry, Plant.

Tivoli B, Beasse C, Lemarchand E, Masson E, 1996. Effect of ascochyta blight (Mycosphaerella pinodes) on yield components of single pea (Pisum sativum L) plants under field conditions. Ann Appl Biol, 129: 207-216.

Citation: Hassan FIM, Eisa YA, Adlan AMA, 2018. Effect of intra-row spacing on growth and yield of two eggplant (Solanum melongena $\mathrm{L}$.) cultivars under Blue Nile State conditions, Sudan. Net J Agric Sci, 6(1): 11-15. 